\title{
Urgences
}

\section{L'argent !...}

\section{Danielle Théberge}

Numéro 15, octobre 1986

Épigraphiques

URI : https://id.erudit.org/iderudit/025339ar

DOI : https://doi.org/10.7202/025339ar

Aller au sommaire du numéro

Éditeur(s)

Urgences

\section{ISSN}

0226-9554 (imprimé)

1927-3924 (numérique)

Découvrir la revue

Citer ce document

Théberge, D. (1986). L'argent !... Urgences, (15), 78-79.

https://doi.org/10.7202/025339ar

Ce document est protégé par la loi sur le droit d'auteur. L’utilisation des services d'Érudit (y compris la reproduction) est assujettie à sa politique d'utilisation que vous pouvez consulter en ligne.

https://apropos.erudit.org/fr/usagers/politique-dutilisation/
Cet article est diffusé et préservé par Érudit.

Érudit est un consortium interuniversitaire sans but lucratif composé de l’Université de Montréal, l'Université Laval et l'Université du Québec à Montréal. Il a pour mission la promotion et la valorisation de la recherche. https://www.erudit.org/fr/ 


\section{Danielle Théberge}

Au prix où est l'argent!

Yann Queffélec: Les noces barbares

L'argent! Fléau social parce que fort mal réparti! Fort et mal! En sera-t-il toujours ainsi? J'ai malheureusement l'impression que oui. Ä moins que...

L'argent! À la base, implicitement ou explicitement, de tout sentiment ou acte de violence: viol, meurtre, haine, privation, délinquance, jalousie, misère, etc. Et j'en passe, car la liste serait vraiment trop longue.

L'argent! Insidieusement imprégné dans nos vies, l'argent nous empêche de voir l'essentiel: la vie elle-même, sa beauté, sa simplicité, son naturel.

Cependant, il existe deux solutions: l'abolition ou la répartition. L'abolition de l'argent nous ferait retourner en arrière, soit à l'époque du troc. Le troc, cette façon positive de se nourrir, se vêtir, se divertir, et... s'épanouir. Pas de violence, point de fraude, ni abus de pouvoir ou détoumement de fonds: la vie redevenue "essence". Et tout le monde y trouverait son compte, mais pas celui de la Banque! La deuxième solution consiste en la répartition de la richesse monétaire. Si on ne peut l'abolir, alors partageons-la... équitablement. Car trop de pays vivent dans une insuffisance "scandaleuse", au moment même où d'autres les regardent mourir sur leurs écrans géants "scandaleux". Et, à l'intérieur même de notre pays capitaliste, l'injustice cohabite trop souvent avec l'excédent, la misère avec l'opulence.

Mais, malheureusement, ces deux solutions (ou propositions) sont probablement vouées à l'échec, puisque leurs réalisations déplairaient sûrement aux dirigeants bien nantis qui gèrent notre (hum!) planète, qui en veulent toujours plus, et dont la soif de l'argent ne connaît pas de frontière. Et puis, le droit de veto leur appartient.

L'argent est synonyme d'injustice. Cessons d'être injuste, c'est urgent! Car tant qu'il y aura de l'argent, nous (les 3/4 de la population terrestre) vivrons dans la misère... Et, de toute manière, si "cela" continue comme "cela", à ce rythme-là, nous avons tous, riches aussi bien que pauvres, un billet pour l'Apocalypse (exceptionnellement égaux dans une triste FIN). 
Donc, ce serait faire preuve d'intelligence (enfin!) que de risquer autre chose, de créer une autre forme de vie avant qu'il ne soit réellement trop tard... pour tout le monde.

Un jour, certains regretteront de ne pas avoir vécu pauvres mais heureux, à l'affût de la Vie. Car le comble de la stupidité ira jusqu'à acheter avec de l'argent... de l'argent. Réagissez!!! 